\title{
MINORITY CHALLENGE OF MAJORITY ACTIONS IN A CLOSE CORPORATION IN ITALY AND THE UNITED STATES
}

\author{
Hypothetical CASE
}

$A, B$ and $C$ each own respectively roo shares of the stock of $X$ corporation. These are all of the outstanding shares, of the par value $\$ 100$ per share. The corporation was organized and began business five years ago. It started with a capital of $\$ 30,000$, contributed by the 300 shares. $X$ corporation has earned (after taxes): Ist year, $\$ 10,000$; 2d year, $\$ 15,000$; 3rd year, $\$ 25,000$; $4^{\text {th }}$ year, $\$ 40,000$; 5 th year, $\$ 50,000-$ a total of $\$ 140,000$. C has repeatedly requested that dividends be paid, but $A$ and $B$, who control the corporation, have refused. ( $A$ and $B$ have large personal incomes and if the corporation paid large dividends, $A$ and $B$ would be subject to a heavy income tax on these dividends). Instead, $A$ and $B$ propose to expand the plant and equipment by an additional capital of $\$ 120,000$; they propose to raise the capital by a new issue of 1200 shares at par, with a right to each shareholder to buy 400 shares (i.e., 4 new shares for each share now held). $C$ claims: that there is no real need for the expansion; that the object of the offering of the new shares is simply to dilute his interest because he is financially unable to take his proportion of the shares, as $A$ and $B$ well know, and that outside parties will neither buy a minority block of shares in a close corporation like this one nor will they loan him money on the security of such a block of shares; that the present shares are worth between $\$ 550-600$ each on the basis of book values and even more on the basis of earning power. He claims that the corporation, which has $\$ 40,000$ cash in hand, none of which is necessary for working capital under the current operation of the company and its current receipts, should pay a dividend of at least $\$ 30,000$ ( $\$ 100$ per share) and that in any event the proposed issuance of new shares should be enjoined (i.e., forbidden by court order). What are C's prospects for compelling the payment of dividends or for enjoining the issuance of the new shares at $\$$ roo per share? 


\section{MINORITY RIGHTS UNDER ITALIAN LAW*}

The hypothetical case presents the following question: Whether a minority stockholder in a corporation has the power. to prevent two decisions taken by the stockholders' assembly, the one refusing to distribute accumulated and available profits and the other authorizing an increase of capital by the issuance of shares upon giving pre-emptive rights to stockholders. It should be added that in the facts under consideration two important circumstances appear. One is that the minority stockholder does not have the financial means to acquire the shares preemptively offered him. In consequence, these shares, being shares in a close corporation and hence not readily disposable on the market, would be acquired by the majority stockholders at par, although actually their value is much greater. The second circumstance is that in the event of distribution of profits by way of dividends, a very substantial income tax would be imposed upon the recipients, particularly on the majority stockholders.

It should be noted at the outset that under Italian Law the corporate organ that has the power of decision in the distribution of dividends in a stock corporation is the stockholders meeting in "ordinary assembly," when it approves the balance sheet, ${ }^{1}$ while to increase the capital it is necessary to have action by a meeting of shareholders in extraordinary assembly, ${ }^{2}$ by way of charter amendment.

The instances in which the decisions of the shareholders can be challenged are stated generally in Art. 2377 of the Civil Code; "Decisions not taken in conformity with law or with the charter can be impugned. ..”

Now, there is no doubt that majority shareholder action sufficient to amend the charter can authorize, in the shareholders' discretion, a capital increase; and if no technical violation of law is encountered, the shareholders' decision is beyond attack.

The situation is somewhat different with respect to dividend distribution of earnings, normally arising and reflected in the accounts, in as much as Civil Code, Art. 2433, providing that the shareholders'

* Roberto Locatelli, third year law student, University of Pavia, Milan, Italy, prepared the portion of this article dealing with minority rights under Italian law.

${ }^{2}$ CoDice Civile, art. 2433 (Italy).

"Anything requiring action by "extraordinary assembly" needs the favorable vote of more than half of the "capital," unless the charter requires a greater proportion. For action by "ordinary assembly" all that is needed is a majority of the duly constituted meeting, which in turn requires a majority of the "capital" for a guorum, unless the charter requires more. CoDice CiviLe, art. 2368 (Italy). 
assembly which approves the balance sheet (state of accounts) "determines the distribution of earnings," has not been uniformly interpreted. According to Ferrara, the assembly would have the further power of distributing or not distributing the earnings, and a shareholder has no individual right except with respect to earnings already ordered distributed. ${ }^{3}$ Of contrary opinion is Fre, who maintains that the shareholder has a subjective right to distribution of earnings which, if not recognized by the assembly, gives right to an action of annulment beyond and outside of Art. 2433." Substantially agreeing with Fre is Ascarelli." Graziani" speaks of a "customary norm" which imposes "a periodical remuneration for the share capital in an amount to be determined by standards of reasonable administration." By case law, the Supreme Court in its decision of June 8, I943, holds that the shareholders' assembly has the discretionary power to distribute or not to distribute the earnings, but this power must be restrained, in addition to the limits imposed by the charter, by the corporation's needs for conservation and for reserve funds for possible future crises.

It would seem that even the views of Graziani and of the case law place only apparent limits on the power of the shareholders' assembly, since they resort to evaluations (such as common interest and prudent administration) entrusted (unobjectionably) to the judgment of the majority. Therefore, although indirectly, even under this view the power over a dividend distribution still falls within the full discretion of the assembly.

On the other hand under Fre's thesis it would be possible to "impugn" the Assembly Act by an annulment based on technical violation of law, without regard to any weighing of the merits. In the absence of this possibility, the assembly decision is beyond attack, just as in the case of increase of capital.

But if an attack is not possible on the plane of technical legality, that is not to say that there is no other way to limit the powers of majorities, who otherwise would be in position to perpetrate abuses.

Full discretionary powers are entrusted to majorities only to be exercised in the common interest. If these powers are used for purposes foreign to the common interest, the majority is abusing the powers en-

\footnotetext{
${ }^{3}$ Imprenditori e Societa, Milano, 1955, page 376.

- Commentario del codice civile 1956; Societa per Azioni, sub. Art. 2433.

- Sui poteri della Maggioranza nelle Societa per Azioni ed alcuni loro limiti, 48 Rivista del DiritTo Commerciale, p. $169,183-189$ (1950).

${ }^{-}$Diritto della Societa.
} 
trusted to it and is committing a substantially illegitimate act, and may be challenged even outside of the text of Art. 2377 of the Civil Code.

The difficulty is to prove that the majority is acting for ulterior purposes, since the majority is the very organ which decides where lies the common interest.

Therefore, the shareholder who "impugns," for reasons of abuse of power or deviation from authorized spheres of action, any decision of the shareholders, such as for instance the increase of capital, is not limited simply to proving the existence or non-existence of a corporate opportunity to invest in expansion (which decision is solely within the competence of the majority); rather, he must prove the deviation of the operation in question from the common interest-for example, the desire of the majority to profit from the inadequate market possibilities of the minority shareholders in order to raid the outstanding shares.

In such a case the shareholder's inquiry into the merits would not be simply to discover absence of merit in the proposal but to ascertain the unlawfulness of the underlying purpose and thus to get a judicial declaration of the illegality of the action.

The theory of abuse of power or deviation in the exercise of power is applied to resolve the grave conflict in legal theory between the necessity of recognizing the assembly's power of discretional evaluation of the exigencies of the corporate enterprise and the necessity of preventing abuse of this power to the detriment of the minority.

This theory, set forth by Carnelutti in $1926,{ }^{7}$ is fully-borne out by text writers and case law. In the decision of the Court of Cassation, May 2I, I95I, one reads:

'The shareholders' Assembly certainly exercises its sovereign prerogative when it proceeds to evaluate the corporate activities and in the light thereof decides that the corporate capital is inadequate to achieve the corporate objectives. If corporate capi$\mathrm{tal}$ is enormously increased against all criteria of wise administration and solely because some shareholders are unable to subscribe for their shares, then from all these circumstances one could draw sufficient indicia for ascertaining whether in the shareholders' decision there abides not so much an exercise of a normal right but rather a fraudulent purpose to eliminate unwanted share-

\footnotetext{
${ }^{7}$ Eccesso de potere nelle deliberazioni dell assemblea delle anonime, 24 RivisTa del Diritto Commerciale 176 (1926).
} 
holders and to concentrate solely in the majority group the newly disposable shares."

In view of what has been said, one must submit that in the hypothetical case there is no lack of legal means for impugning the corporate stand taken by the action of $A$ and $B$ to withhold dividends and increase the capital.

With respect to the dividend distribution, if one were to follow that segment of doctrine (i.e., views expounded by writers on the subject) that holds that the assembly cannot refuse to distribute at least in part, or to the extent indicated by arbitrium boni viri, the earnings regularly available from operations as revealed by the financial statement at the close of the fiscal period, it would seem clear that $C$ should no doubt be entitled to have the corporation declare a dividend of $\$ 30,000$, particularly since this sum does not appear to be needed in the business.

If one were to hold, instead, that the shareholder assembly has full and complete power over dividend matters, as well as capital increase, the shareholder would be put to more extreme measures of proof of abuse of power. In this event, it would not suffice for $C$ to prove that the $\$ 30,000$ sum is not needed in the business and hence that its retention does not comport with sound administration or that there is no sound business reason for such a considerable capital increase. Affirmative conclusions in those directions would be only valid factual bases from which it would then still be necessary to demonstrate that the majority's purpose was really to avoid heavy income tax incidence and to profit from $C$ 's inability pre-emptively to take of his shares so that the others can pick up shares worth $\$ 500$ to $\$ 600$ for a price of $\$ 100$.

In view of the fact that, because of $C^{\text {s }}$ financial position, the contemplated capital increase, if achieved by the proposed issuance of shares at par, would affect $C$ not merely by diminishing his proportional participation in the corporate capital but also by diluting his holdings by tens of thousands of dollars, and in view of the further fact that the capital increase could be effectuated by other methods not prejudicial to $C$, if the assembly does not adopt these other methods (e.g., issuance of shares at discount or gratuitously so as to equalize the present corporate capital with subsequent issues at par) it can plausibly be maintained that its real motive is not to increase the investment in the company. 
The same considerations apply to the distribution of the $\$ 30,000$ on hand.

$C$ must convince the court that the earnings are being withheld because $A$ and $B$ 's motives are to avoid heavy income taxes (there is no corporate reason for withholding them) if $C$ is to obtain annulment of the shareholders' action. 


\section{MINORITY RIGHTS IN THE UNITED STATES}

In the United States the declaration of dividends is considered a matter of managerial business judgment falling within the discretionary authority of the board of directors, who can act without ascertaining the desires of the shareholders or, indeed, even against the express desires of the stockholders. ${ }^{1}$. Similarly, the issuance of additional shares within the number authorized by the charter is generally within the authority of the board of directors. ${ }^{2}$ However, the authority of the board of directors does not extend to making fundamental changes in the character or organization of the corporation, such as a charter amendment increasing the total amount of stock which the corporation is authorized to issue. ${ }^{3}$ Even so, under the facts of the hypothetical case, the distinction is academic since, through their ownership of two-thirds of the stock, $A$ and $B$ can control the board of directors and can carry or defeat any issue submitted to the stockholders for approval. ${ }^{4}$ By exercising this dual control of directors' and stockholders' action, $A$ and $B$ have the legal power to exercise the ultimate decision on dividend declarations and new stock issuance.

Recognizing that the power residing in majority stockholders may be subject to abuse, the American courts uniformly hold that there are some situations in which an exercise of their equity power is justified to curb technically legal actions of a corporation's majority which are oppressive to the minority. ${ }^{5}$. Courts interfere in corporate affairs with

\footnotetext{
${ }^{2}$ Ballantine, Corporations $\$ 42$ (rev. ed. 1946).

${ }^{2}$ Ibid.

${ }^{3}$ Ibid.

tThe one exception to this occurs in Virginia, where the charter can be amended only by a vote of more than $/ 3$ of the shares. VA. CODE ANN. $\$ 13.1-56$ (1956 repl. vol.). In several states, however, the charter may provide for a larger vote for amending the charter than the statute requires. The following statutes have such provisions: ALA. CODE tit. 10, § 18 (Supp. 1953); ARK. STAT. § 64-107 (1947); CAI. CoRP. CODE § 3632 (1955); Colo. Rev. Stat. AnN. § 31-3-3 (1953); Fla. Stat. § 608-18 (1956); IDAHO CODE ANN. § 30-146 (1947); IND. ANN. STAT. § 25-223 (1948); KY. REv. Stat. ANn. § $271-445$ (ig55); La. Rev. Stat. \$ x2:42 (1950); Minn. Stat. AnN. § 301.37 (1947); Miss. CODE ANN. $\S 5312$ (1956); NEv. Rev. STAT. tit. $7, \S 78.390$ (1957); N.C. Gen. Stat. § 55-100 (Supp. 1957); Tenn. CODE ANN. § 48-120 (1955); VT. STAT. \$ 5766 (1947); WASH. Rev. CODE $\$ 23.12 .060$ (1951).

${ }^{5}$ Ballantine, $\$ \S 66,158,205,231$ (rev. ed. 1946). See also Comments, 2 Duke B.J. II3 (1952); 9 Hastings L.J. 306 (1958); 35 N.C.L. REv. 271 (1957);
} 
much reluctance, however, and a minority stockholder seeking the aid of an equity court to challenge decisions concerning dividends or the sale of additional shares of stock is required to sustain a difficult burden of proof. ${ }^{\circ}$ This judicial reluctance, with its accompanying onerous burden of proof, is probably grounded in the realization by the courts that they are ill-equipped to make decisions on corporate policy in opposition to the informed wishes of the directors and stockholders.

One general theory by which many courts approach the problem of minority challenge of majority decisions holds that the majority stockholders, when actually controlling the corporation, ${ }^{7}$ owe a fiduciary duty to the minority stockholders. ${ }^{8}$ While application of this fiduciary concept by the courts is not uniform, the variations in its application occur not so much because of definitional differences as in the intensity of the applications of concepts such as good faith and fair dealing which are the core of this rule. ${ }^{9}$ When the courts state that the majority owes the minority a fiduciary duty, it is not meant that the majority may never act in its own interest when to do so would contravene the interests of the minority group. ${ }^{10}$ The typical question confronting the courts

4I VA. L. Rev. 77 (1955); Notes, 10 Rutgers L. Rev. 723 (1956); 7 WESTERN Res. L. REv. 467 (1956).

'Waldrop v. Martin, 237 Ala. 556, I88 So. 59 (1939); Allaun v. Consolidated Oil Co., 16 Del. Ch. 318 , 147 Atl. 257 (1929); Robinson v. Pittsburgh Oil Refining Corp., 14 Del. Ch. 193, 126 Atl, 46 (1924); Annot., 55 A.L.R. 8, 44 (1928).

The courts do not require that the control group have over $50 \%$ of the stock before they will impose the fiduciary relation. The real criterion is whether the group exercises effective control. Hyams v. Calumet \& Hecla Mining Co., 221 Fed. 529 (6th Cir. 1915); Kavanaugh v. Kavanaugh Knitting Co., 226 N.Y. 185, 123 N.E. 148 (rgig); Note, 7 WEstern Res. L. REv. 467, 468 (1956).

${ }^{8}$ Zohn v. Transamerica Corp., I6z F.2d ${ }_{36}$ (3rd Cir. 1947); Lebold v. Inland S.S. Co., 82 F.2d 35 I (7th Cir. r 936); Ervin v. Oregon Ry. \& Nav. Co., 27 Fed. 625 (C.C.S.D.N.Y. 1886); Consolidated Gold Mining and Milling Co. v. Gauthier, 22 Ariz. 67, 193 Pac. I0z1 (1920); Gaines v. Long Mfg. Co., 234 N.C. 340, 67 S.E.2d 350 (1951); Heller v. Baylan, 29 N.Y.S.2d 653 (Sup. Ct. 1941); Patton v. Nicholas, 154 Tex. $3_{55}, 279$ S.W.2d 848 (1955). See Note 7 WESTERN Res. L. ReV. 467 (1956), for a good review of the historical development of this concept.

- See Comment, 9 Hastings L.J. 306 (1958).

${ }^{30}$ For example, courts have upheld each of the following transactions: the issuance of stock to majority stockholders to pay a debt owed to the stockholders by the corporation. Bellows v. Porter, 201 F.2d 429 (8th Cir. 1953); the issuance of stock to a stockholder in payment for property sold to the corporation by the stockholder, Gamble v. Queens County Water Co., I23 N.Y. 91, 25 N.E. 201 (1890); and the issuance of new stock to obtain money to pay off mortgages held by the majority stockholders, Schramme v. Cowin, 205 App. Div. 520, 199 N.Y. Supp. 98 (rst Dept. 1923). In each of these situations, minority stockholders complained that they were unable to purchase their pro-rata share of the new issue and thus their proportionate share of the corporate 
is one of degree, therefore, and the decision in each case will probably turn on whether the court considers the majority's objectives and the means used to attain those objectives fair and decent with respect to the minority. ${ }^{11}$ Crucal in cases of this type are the notives of the majority, which usually can be established only after a close analysis of such facts as the business needs of the corporation, the nature of the particular acts questioned by the minority, the type of business done by the corporation, and the past and present relationship of the contesting parties.

Other courts phrase the rule differently, choosing to interfere only when specific acts of the control group can be characterized as abusive of discretion, ${ }^{12}$ unreasonable or arbitrary, ${ }^{13}$ or in bad faith. ${ }^{14}$ Despite the terminology employed, each of these concepts is essentially equivalent to the fiduciary duty rule, with accompanying emphasis on a measuring of the fairness and decency of the majority's acts which affect the minority.

A few decisions state that the coinplaining stockholder must prove either detriment to the corporation itself or fraud before he can secure relief. ${ }^{15}$ These decisions, if taken at face value, would seem to impose a more difficult burden of proof than the aforementioned tests. There are several reasons, however, why this may be an inaccurate conclusion. The facts of some of the cases in which these requirements were stated were such that the courts would probably have reached an identical conclusion under any rule. ${ }^{16}$ And although some jurisdictions have prec-

assets would be reduced, but their pleas were rejected because the transactions in question were not unduly unfair.

${ }^{11}$ See Latty, Minority Shareholder Protection in American Corporation Law, 1957 JoURNAL OF BUSINESS LAW 229.

${ }_{12}$ Jones v. Motor Sales Co., 322 Pa. 492, 185 Atl. 809 (1936).

${ }^{13}$ Channon v. Channon Co., 218 Ill. App. 397 (1920).

14 Stevens v. United States Steel, 68 N.J. Eq. 373, 59 Atl. 905 (1905); Tefft v. Schaefer, 136 Wash. 302,239 Pac. 837 (1925).

${ }^{15}$ Bellows v. Porter, 201 F.2d 429 (8th Cir. 1953); Southern Pac. Co. v. Lowe, Collector of Internal Revenue, 238 Fed. 847 (S.D.N.Y. 1917); Gamble v. Queens County Water Co,, 123 N.Y. 9I, 25 N.E. 201 (1890); Mobile Towing \& Wrecking Co. v. Hartwell, 208 Ala. 420, 95 So. 191 (1922).

${ }^{10}$ In Gamble v. Queens County Water Co., supra note ${ }_{15}$, the question was whether the minority shareholder could enjoin the issuance of stocks and bonds worth $\$ 110,000$ to another shareholder in payment for a system of pipes which had been sold to the corporation. The opinion of the court dealt extensively with the question of the worth of the system of pipes to the corporation, concluding that $\$ 110,000$ was not an unreasonable price. Since the corporation got what it paid for, it does not appear that the transaction was so unfair to the complaining stockholder as to constitute bad faith. The share of the minority stockholder in the corporation was decreased in proportion 
edents which seem to require a showing of actual fraud, other decisions from the same jurisdictions sometimes state that proof of bad faith is sufficient, indicating that the two terms may have been used interchangeably. ${ }^{17}$ There is also ostensible authority for the proposition that fraud is required which in fact did not arise in a case between minority and majority groups in a corporation. ${ }^{18}$ These considerations lead to the conclusion that, although courts occasionally speak in terms of detriment to the corporation or fraud, these ostensibly more stringent standards usually do not impose upon minority interests a more difficult burden of proof than that demanded under the unfairness approach described previously.

Thus it appears that the courts exercise their equity powers on the basis of a subjective value judgment as to the fairness of the majority's treatment of the minority. This general proposition means little, however, when considered apart from the facts of the individual cases. A more revealing analysis of the problem can be made in terms of specific facts which have prompted courts to grant relief, and in this respect, a number of cases have dealt with problems closely analogous to $C^{\text {'s. }}$.

One factor which has been considered important by the courts is the business need of the corporation. Although this is ordinarily a question of business judgment, and hence within the discretion of the directors, courts have on occasion examined the amount of capital needed in the business concerned to ascertain if there has been an abuse of discretion. While courts have upheld continued dividend withholding where the

to that of the recipient of the stocks and bonds, but the total value of the corporation's assets were also increased proportionately.

In Bellows v. Porter, supra note 15 , the plaintiff complained of the issuance of $\$ 100,000$ worth of stock to a majority stockholder in exchange for the canceling of an indebtedness of $\$ 100,000$ which the corporation owed the majority stockholder. The plaintiff made no showing that the debts owed by the corporation to the majority stockholder were not valid, and gave no proof that the corporation did not benefit by haviug its current liabilities reduced. Further, there appears to have been no reason why the majority stockholder should have been treated differently from other corporate creditors. Under these circumstances, it seems the court could have concluded that the whole transaction was not really unfair to the plaintiff.

${ }^{17}$ In the decision of Mobile Towing \& Wrecking Co. v. Hartwell, 208 Ala. 420, 95 So. 191 (1922), there is language to the effect that fraud must be shown. As authority for this proposition, the court cites, among other cases, Wolf v. Uncerwood, $96 \mathrm{Ala} .329$, II So. 344 (1892), which states that bad faith is sufficient. The case of Holcomb v. Forsyth, 216 Ala. $486,11_{3}$ So. 516 (1927), states that good faith is the criterion.

${ }^{18}$ Southern Pacific Co. v. Lowe, Collector of Internal Revenue, 238 Fed. 847 (S.D.N.Y. 1917). There the corporation and the tax collector were the contesting parties, and there was no mention of any conflict between the majority and minority. 
business was of a kind which required substantial working or expansion capital, ${ }^{19}$ they have compelled dividends when it appeared that profits had been withheld wholly out of proportion to the business needs. ${ }^{20}$ Similarly, when confronted with the question of a new stock issue, courts have been willing to examine the need for new financing. ${ }^{21}$ As a practical matter, however, it is very difficult to prove the absence of a valid business reason for withholding of dividends or issuance of new stock. In today's complex business world, there are few situations indeed in which a court can assert with confidence that plans of the directors for expansion are completely unwarranted. It might be somewhat easier to prove that a corporation has accumulated an unduly large surplus, ${ }^{22}$ but here again a moment's reflection will indicate the difficulty involved in convincing a court that it should override the directors' judgment. These difficulties of proof may explain the courts' reluctance to grant relief

\footnotetext{
${ }^{10}$ In Gesell v. Tomahawk Land Co., 184 Wis. 537, 200 N.W. 550 (1924), the court examimed the nature of the corporation's holdings and found them to be primarily unimproved lands. The court then concluded that the defendant's policy of expending capital to improve the lands in order to secure a larger price for the land was not an abuse of discretion.

In Raynolds v. Diamond Mills Paper Co., 69 N.J. Eq. 299, 60 Atl. 941 (1905), the court took notice of the fact that all of the great industries of the United States had expanded during the 20 years preceding the bringing of the case in question. The court stated further that the profit per unit in the defendant's industry was decreasing and that increased production was the only way to keep profits up. Evidence that the company would have had to curtail its business because of an inability to meet all of its orders in the absence of expansion was also mentioned. These factors, plus the fact that the capital of the corporation in question had not yet been doubled as a result of expansion, caused the court to conclude that the expansion in question was justified, and that there had not heen unreasonable dividend withholding.

${ }^{20}$ In Crichton v. Webb Press Co., $11_{3}$ La. 167, 36 So. 926 (1904), the corporation began business with a capital of $\$ 26,000$. Before the court was confronted with the case, profits of $\$ 294,683.55$ had already been made. The court decided that a dividend of at least $\$ 50,000$ should be paid since the corporation had made profits of more than 10 times the amount of original capitalization.

In Hiscock v. Lacy, 9 Misc. 578, 30 N.Y.S. 860 ( 1894 ), one of the defendants had admitted at trial that there was never a time when the bank was not able to pay a dividend. Also important to the court was the fact that the corporation's surplus was about $\$ 200,000$, or the equivalent of $1 / 2$ of its capital, and more, proportionately, than the corporation had possessed in the years when it was paying dividends annually.

${ }^{21}$ Bellows v. Porter, 201 F.2d 429 (8th Cir. 1953); Schramme v. Cowin, 205 App. Div. 520, 199 N.Y.S. 98 (1st Dept. 1923).

${ }^{22}$ Dodge v. Ford, 204 Mich. 459, 170 N.W. 668 (1919), affords an example of this. The court approved Ford's expansion plan, but there was even more surplus available than was needed to carry out the plan. Therefore, a simple arithmetical calculation was sufficient to show the court that there was enough surplus to pay a dividend.
} 
based solely on their judgment that the acts in question were not justified by business needs of the corporation. ${ }^{23}$ If $C$ can prove, as he has alleged, that there is in fact no real need for expansion and that cash on hand is not needed for working capital, he will have satisfied one of the usual prerequisites to relief.

Some courts have been influenced by the limited market for the stock of a close corporation in deciding whether to order a dividend. ${ }^{24}$ Although a clear case is presented when it is shown that dividends were withheld as part of an attempt to force a minority stockholder out of a corporation, judicial intervention would seem to be appropriate in cases presenting less aggravated circumstances, such as prolonged and unreasonable withholding of dividends in a period when the corporation is making high profits. In the absence of an adequate market, stockholders in a close corporation can seldom realize the increased value of their shares which has resulted from accumulated profits. Thus, the close corporation stockholder must rely almost exclusively on dividends for a return on his investment. This factor is rarely mentioned by the courts, but its frequent occurrence in cases where the minority succeeds in having a dividend ordered by the courts indicates that it probably has some influence on the courts. ${ }^{25}$ The absence of a ready market would thus appear to weigh in $C^{\prime}$ s favor.

The type of evidence which will usually be considered most significant by the courts is that of a conflict of interest between the majority and minority groups, resulting in the majority's taking unfair advantage of its power to indulge self-interests. ${ }^{26}$ For example, in one interesting

${ }^{23}$ A reading of the cases cited in footnotes 19 through 22, supra, indicates clearly that the courts did not rely solely on the business needs of the corporations in reaching their decisions. In the case of Raynolds v. Diamond Mills Paper Co., 69 N.J. Eq. 299, 6o Atl. 941 (1905), however, there is a suggestion that there might be certain extreme situations in which a court should force a dividend solely because of unreasonable expansion at the expense of dividends.

"2 Raynolds v. Diamond Mills Paper Co., supra note 23; Steven v. Hale-Haas Corp., 249 Wis. 205, 23 N.W.2d 620 (1946).

${ }^{26}$ Comment, 2 Duke B.J. I I3 (1952). See also Annot., 55 A.L.R. 8, 62 (1928), which comments on the importance of this factor. One could argue, however, that the reason this factor is present in most of the cases where dividends are ordered is simply that most of the situations where court action is needed involve the small close corporation.

${ }^{20}$ Courts have given relief when it was found that the directors were withholding profits for the purpose of paying off corporate debts incurred in self-dealing contracts, Crichton v. Webb Press Co., II3 La. I67, 36 So. 926 (1904); where there was an attempt to force a minority shareholder completely out of the corporation, Flemming v. Heffner \& Flemming, 263 Mich. 56I, 248 N.W. 900 (1933); and where majority 
case where a court held for the minority, a conflict of interest took the form of a restraint of dividends to avoid the imposition of high bracket income taxes on the majority. ${ }^{27}$ Since in the hypothetical problem $C$ has alleged that $A$ and $B$ are furthering their interests by avoiding higher tax rates at the expense of his dividend expectations, that case seems especially cogent. $C$ 's interests are adverse to those of the corporate majority in another respect since $A$ and $B$ know that $C$ cannot obtain capital to purchase his pro-rata share of the new issue of stock. If the shares are sold at par, a figure considerably less than their actual value, ${ }^{28} A$ and $B$ will simultaneously fatten themselves, dilute $C$ 's interest in the corporate surplus, and decrease $C^{\text {'s }}$ proportional interest in the venture. Some courts have appreciated the plight of a shareholder who is unable to purchase his pro-rata share of a new stock issue and, when it appeared that the majority was taking an unconscionable advantage of his plight, have held for the complaining stockholder. ${ }^{29}$ Other courts have held that if the stockholder cannot exercise his preemptive rights, his only recourse is to sell those rights. ${ }^{30}$ While the former rule has been articulated only in more recent cases, the latter rule was first developed years ago. This contrast may mark the beginning of a trend toward greater judicial solicitude for a stockholder in $C^{\prime}$ s plight. ${ }^{31}$

\section{Conclusion}

Although the facts alleged in this hypothetical problem do not represent a great quantity of evidence, they may be of a sufficient quality

shareholders who held management positions were pursuing a policy of high salaries at the expense of dividends, Hiscock v. Lacy, 9 Misc. 578, 30 N.Y.S. 860 (1894).

${ }^{27}$ Whittemore v. Continental Mills, 98 F. Supp. 387 (D.Me. 195I). Also important was the fact that continued expansion of the surplus might subject the corporation to a penalty under Int. Rev. Code of $1954 \$$ I02. See T. D. 4914, 1939-2 Cum. Bull. ro8.

${ }^{28}$ The par value of stock has no constant relation to its actual value. The stock's book value or earning power, particularly the latter, are much more reliable methods of approximating actual value.

${ }^{20}$ Bennett v. Breuil Petroleum Corp., 99 A.2d 236 (Del.Ch. 1953); Gaines v. Long Mfg. Co., 234 N.C. 340,67 S.E.2d 350 (1951).

${ }^{30}$ Bellows v. Porter, 201 F.2d 429 (8th Cir. 1953); Schramme v. Cowin, 205 App. Div. 520, 199 N.Y. Supp. 98 (1st Dept. 1923).

${ }^{31}$ Although there is language in the cases which indicates that there are two conflicting rules on this point, there are significant factual differences in the two groups of cases. In the cases cited which espouse the old rule, there was no allegation that the majority was trying to squeeze the minority out of the corporation, but there were such allegations in the cases cited which followed the new rule. Although the courts did not fully articulate the significance of this factor in their opinions, it may account for the different rules. 
to prompt a court to grant relief, since $C$ can perhaps create a suspicion of "squeeze-out" or deliberate dilution sufficient to induce the court to find bad faith, abuse of the fiduciary relation, or any other semantic combination it may employ when it grants relief.2 In particular, the thoroughgoing exploitation of $C$ 's position would seem to require explanation by the majority. The plan of the majority to issue new stock at par is even more indicative of an unfair use of power when it is realized that an alternative plan-issuance of new stock at some figure realistically closer to its actual value-is available by which capital can be raised without so extensively diluting $C$ 's interest in the corporation. An insufficient explanation of these particular circumstances would probably enable $C$ to exact a remedy, even if $A$ and $B$ should present plausible evidence on the issue of the corporation's business need.

A court resolving a case such as this in favor of the plaintiff would probably follow the reasonable policy of gauging the severity of the judgment by the amount and kind of proof offered by the plaintiff. Using this criterion, it would take a hardy court to order $A$ and $B$ to declare a dividend ${ }^{33}$ and to require that any new shares be issued at true value, since it is probable that the evidence on the issue of business need will not be overwhelmingly weighted in C's favor. Thus the relief in the hypothetical case would most likely take the form of an injunction forbidding $A$ and $B$ to issue new shares at a price less than some figure found by the court to be close to their actual value.

\footnotetext{
${ }^{32}$ There is language in the following cases which indicates that proof of factors such as those alleged by $C$ would result in a decision for $C$ : Steven v. Hale-Haas Corp., 249 Wis. 209, 23 N.W.2d 620 (1946); Bennett v. Breuil Petroleum Corp., 99 A.2d 236 (Del.Ch. 1953); Gaines v. Long Mfg. Co., 234 N.C. 340,67 S.E.2d 390 (r95 r).

${ }^{33}$ On the matter of a dividend, $C$ would face a somewhat easier task in North Carolina as a result of a recent state statute. This statute allows at least $20 \%$ of the stockholders of a corporation automatically to force a declaration of dividends on at least $1 / 3$ of the profits of the current operations. N.C. GEN. STAT. § 55-50(i) (1957 Supp.).
} 